\title{
PERAN POLITIK PEREMPUAN MELALUI SINOMAN DI DESA GROBOG WETAN TEGAL
}

\author{
Zaki Mubarok \\ Sekolah Tinggi Agama Islam Bakti Negara (STAIBN) Tegal \\ zakimubarok862@gmail.com
}

\section{ABSTRAK}

Sinoman dirumuskan sebagai tradisi saling membantu antar anggota masyarakat dalam aspek politik, sosial dan agama. Sinoman lazim dilakukan perempuan baik berupa pemberian materi atau pekerjaan nir transaksional. Artikel ini bertujuan untuk mendeskripsikan tradisi Sinoman di desa Grobog Wetan Tegal dalam konteks politik pemilihan kepala desa. Artikel ini menyimpulkan sinoman menjadi mekanisme vote gatter, kampaye, memberi dan menyajikan logistik selama pemilihan kepala desa. Meski berperan penting, perempuan tidak otomatis menjadi figur yang berada di tengah kekuasaan atau masuk dalam inti struktur kekuasaan. Sebaliknya, ia menjadi bagian luar dari sistem kekuasaan atau politik yang berjalan. Peran penting mereka dalam politik desa didasarkan pada semangat ibadah yang bersumber pada ajaran patuh kepada perintah suami atau laki-laki yang berkedudukan sebagai imam. Karena pilihan politik suami menjadi pilihan politik yang harus dipatuhi istri atau saudara perempuan lainnya. Meski demikian, peran perempuan dalam Sinoman memiliki pengaruh atas pembagian kekuasaan untuk suami atau saudara laki-lakinya di desa. (yang dipedomani bahas Indo, warna kuning blm ada $\mathrm{p}$

Kata Kunci; Sinoman, Politik, Gender

\section{ABSTRACT}

Sinoman is defined as a tradition of mutual assistance among members of the community in the political, social, and religious context. Sinoman is commonly done either in the form of material or 
non transactional jobs and generally done by women. This article aims to describe the Sinoman tradition in the village of Grobog Wetan Tegal in the context of the politics of village head elections where it becomes a mechanism for vote getter, campaigning, giving and presenting logistics. This research is qualitative with a case study approach and the data sources are obtained through interviews and documentation. The result shows that although playing an important role, women do not automatically become figures who are in the middle of power or included the core of the power structure. Instead, they become an outside part of the running power or political system. Their important role in village politics is based on the spirit of worship originating from the teachings that women must be obedient to the orders of husbands or men who are considered as leaders. Therefore, wives or other sisters must follow the husband's political choice. However, the role of women in Sinoman has an influence on the distribution of power for their husbands or brothers in the village.

Kata Kunci; Sinoman, Politics, Gender

\section{A. Pendahuluan}

Secara sederhana sinoman dalam masyarakat Kabupaten Tegal dapat dirumuskan sebagai tradisi saling membantu antar anggota masyarakat dalam kegiatan pengajian, hajatan pernikahan atau khitanan, santunan anak yatim bahkan pemilihan kepala desa yang lazimnya dilakukan oleh perempuan. Dalam konteks pemilihan kepala desa, misalnya, sinoman dilakukan atas dasar cita-cita melahirkan pemimpin yang adil bagi seluruh masyarakat diyakini sebagai bentuk ibadah yang akan dipertanggungjawabkan di akhirat kelak. Karenanya perempuan desa memberikan bantuan logistik dan tenaga kepada calon yang didukung tanpa mendasarkan pada akad hutang piutang atau jual beli. Kenyataan yang ada, sinoman dalam politik praktis melahirkan kekuatan (power) yang berpengaruh dalam dinamika politik masing-masing kepala desa. Calon kepala desa yang mampu mengorganisir perempuan memiliki kesempatan terpilih lebih kuat.

Hal yang tidak bisa dipisahkan dalam sinoman adalah pengaruh doktrin agama bahwa laki-laki merupakan pemimpin kaum perempuan dalam QS. Al-Nisa': 34 dalam potongan ayat arrijalu qowwamuna ala alnisa. Konteks masyarakat desa Grobog Wetan yang religious menjadikan 
peran suami atau lelaki berpengaruh kuat secara tekstual.Pilihan politik suami atau saudara laki-laki harus dipatuhi oleh istri atau saudara perempuan. Bentuk kepatuhan diwujudkan dalam sinoman politik, antara lain melakukan kampanye, memberikan logistik atau sekedar mempersiapkan, menyajikan makanan bagi masyarakat yang bertamu di rumah calon kepala desa pilihan suami atau saudara laki-laki. Perempuan yang melanggar berarti melanggar perintah Allah dan kelak mendapatkan dosa serta siksaan di akhirat.

Dari sisi religiusitas, desa Grobog Wetan memiliki dinamika pemikiran dan gerakan agama, sosial dan politik yang tinggi. Dengan jumlah penduduk sebanyak 7545 jiwa, desa ini dapat dikategorikan sebagai desa agamis ditandai dengan dua Pondok Pesantren (Nurul Huda dan Al-Falah), Raudlatul Athfal (RA), Madrasah Ibtidaiyah, Madrasah Tsanawiyah (MTs), dan Madrasah Aliyah. Selain itu, terdapat tiga masjid yang berfungsi selain sebagai saraan ibadah sholat juga sebagai tempat pengajian hari-hari besar Islam, 35 unit mushola, dan rutinitas pengajian yang diadakan warga desa ini.

Dalam tujuh hari tidak pernah luput dari pengajian yang diikuti oleh ibu-ibu dengan sebutan ahadan, senenan, selasanan, reboan, kemisan, jum'atan dan sabtunan yang dilakukan baik secara bergilir di rumah warga (ketiban) maupun di majlis taklim atau mushola yang telah ditentukan. Bahkan dalam sehari ada dua jenis ahadan atau selasanan yang dilakukan oleh dua kelompok pengajian/jamiyyah di tempat berbeda dengan pengasuh yang berbeda pula. Sedangkan untuk bapak-bapak lebih terkonsentrasi pada malam jum'at (jum'atan) dan malam minggu (ahadan).Tak jarang nampak persaingan dalam hal jumlah peserta pengajian dan kemasan pengajian dimana masing-masing berusaha mendapatkan sebanyak mungkin pengikut pengajian. Seringkali perbedaan figur calon kepala desa, turut mempengaruhi “persaingan” tersebut. Dengan demikian, tergambar bahwa potensi kekuatan politik perempuan terkonsentrasi pada masing-masing jam'iyyah pengajian.

Dalam amatan penulis, peran perempuan dalam dinamika sosial, keagamaan dan politik masyarakat desa Grobog Wetam juga tergolong signifikan. Dalam kegiatan pengobatan gratis, distribusi beras miskin, Pos 
Pelayanan Terpadu (Posyandu) dan kegiatan lainnya, perempuan menjadi aktor utama. Loyalitas perempuan didasarkan pada 'spirit tradisi sinoman' yang sudah turun temurun dan merupakan bagian dari penghayatan dan praktek keagamaan.Sinoman telah menjadi bagian yang integral dalam praktek keagamaan masyarakat Desa Grobog Wetan.

Praktik Sinoman Politik oleh perempuan misalnya dilakukan Nani. Sebagai istri ketua Rukun Tetangga (RT), ia melakukan peran domestik dan publik di Desa Grobog Wetan. Selain menyelesaikan tugas rumah tangga, ia bekerja, mengikuti pengajian, dan melakukan charity dengan membagikan beras miskin kepada warga setiap bulan maupun kegiatan lain yang berkaitan dengan jabatan suaminya. Aktivitas sinoman Nani merupakan representasi sinoman dalam ranah politik desa atau "sinoman politik". Ketika diwawancarai, landasan teologis terasa begitu kuat dalam diri Nani:

"Nggeh ngaten niki, mas. Sa' sagede kula ngrewangi bapake. Kan ibadah, mas. Hehe.. Wong bapake siweg nyambet damel, nggeh kula sing nangani raskin. Penting lancar. Insyaallah mangke angsal ganjaran".

(Ya begini, mas. Sebisa saya membantu bapak [suami]. Kan ibadah, mas. Hehe.. [Nani tertawa-red]. Bapak sedang bekerja jadi saya yang nangani [membagikan] raskin. Yang penting lancar. Insyaallah nanti dapat pahala). (Wawancara dengan Nani)

Peran penting perempuan ini tidak sebanding dengan penguasaan perempuan atas jabatan penting di desa ini. Dalam konteks politik,belum pernah ada kepala desa perempuan. Duduknya perempuan pada birokrasi desa mulai Pamong Desa, RT, dan RW pun demikian. Hal yang sama juga terjadi dalam lembaga pendidikan di Desa Grobog Wetan baik Madrasah Ibtidaiyah (MI), Madrasah Tsanawiyah (MTs) dan Madrasah Aliyah (MA) sepanjang sejarah tidak pernah dipimpin oleh perempuan. Bahkan dalam jamaah pengajian perempuan, pembicara atau penceramah perempuan atau "kyai perempuan" tidak ditemui. Fenomena inilah yang penulis pahami sebagai salah satu tengara yang menunjukan keunikan dalam pemaknaan kesetaraan gender. Peran perempuan direduksi dalam perspektif laki-laki dengan menggunakan agama.Sebuah pemaknaan yang dalam pandangan feminism lazim dipahami sebagai ketimpangan, tidak setara dalam mengamalkan gender. 
Dalam konteks bangsawan perempuan Jawa, Sukatno CR memberi inspirasi dan data tentang bagaimana perempuan secara seksual dalam tradisi keraton ditempatkan dalam kondisi subordinat oleh para lelaki dan bangsawan Jawa. Seks-yang dimaknai sebagai pencandraan terhadap perempuan dengan lebih memperhatikan aspek biologis dan berjalinan dalam manifestasi kesetaraan gender-menurut Otto, meski konsepsinya diturunkan dan dari konstruk masa silam Jawa, tetapi nilai, berikut konsekuensi dan relasirelasinya masih banyak diyakini dan dipraktikan dalam kehidupan sehari-hari (Sukatno, 2002: 98). Ini pula yang menjadikan bentuk ritualisasi seks dan mistik_teologi_oleh manusia selalu diboyong ke ranah domestik, karena di dalam wilayah domestik ini, segala bentuk hukum formal dan sosialtermasuk rezim kuasa tertentu, seperti rezim moral, bahasa, politik, dan nilai yang berasal atau merupakan diaspora dari dunia spiritual pada umumnya, seperti sistem iman/keyakinan dapat dengan leluasa dikontrol dan direduksi sedemikian rupa oleh manusia.

Sikap batin perempuan Jawa terurai dalam kondisi, makna dan strategi perempuan Jawa dalam konteks kekuasaan. Kekuasan perempuan Jawa adalah kemampuannya untuk mempengaruhi, menentukan, bahkan mungkin mendominasi suatu keputusan. Kemampuan wanita untuk mempengaruhi pengambilan keputusan tersebut bukan semata-mata pada saat keputusan itu diambil, melainkan merupakan sebuah proses yang panjang dari proses adaptasi, pemaknaan kembali, hingga strategi dominasi (Handayani dkk, 2001: 118).

Peran politik perempuan Desa Grobog Wetan melalui sinoman dalam perspektif gender dapat dilihat dalam dua hal pertama, konsep kebenaran tertinggi bagi perempuan dalam relasi gender. Kedua, makna kesetaraan dalam peran politik perempuan di Desa Grobog Wetan.

Riset ini berjenis kualitatif, data dalam penelitian ini diperoleh dari masyarakat Desa Grobog Wetan dalam melaksanakan sinoman dengan berbagai latar belakang pendidikan dan profesi, seperti petani, buruh, agamawan, pemerintah desa, cendekiawan. Data sekunders ebagai tambahan untuk lebih memperjelas dalam melakukan penelitian terhadap masalah ini diperoleh baik dari majalah, koran, jurnal maupun literatur lain terkait tradisi 
sinoman.

Melalui pendekatan fenomenologi, penelitian ini hendak menyingkap dunia dalam (emik) yang mana peneliti dan tineliti melebur dan mengabaikan perbedaan posisi keduanya. Mengutip Husserl, fenomena hakikatnya adalah refleksi dari suatu realitas yang kompleks, yang hanya dapat dicapai melalui upaya sungguh-sungguh dengan cara menerobos terhadap dunia pengalaman subjektif yang penuh makna. Dunia tindakan individu merupakan pengalaman yang direfleksikan dalam tindakan yang penuh arti dan makna (Waters, 1994:31).

\section{B. Pembahasan}

\section{Konsep Kebenaran Tertinggi Kesetaraan Relasi Laki-Laki- Perempuan}

Salah satu faktor yang mendukung suksesnya misi Nabi Muhammad dengan al-Qur'an sebagai wahyu dan referensinya adalah karena ajaranajaran yang dibawanya adalah ajaran yang berisi pembebasan dari berbagai penindasan. Termasuk diantaranya adalah pembebasan perempuan dari lingkaran misoginis dan tekanan patriarki. Secara khusus, Nabi memberikan perhatian terhadap relasi lelaki dan perempuan dan menyatakannya relasi keduanya semestinya seperti adalah saudara kandung.

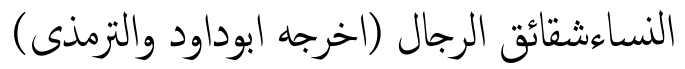

Artinya; Kaum perempuan adalah saudara kandung kaum laki-laki. (H.R Abu Dawud dan at-Turmudzi)

Turunnya al-Qur'an dan pernyataan Nabi SAW di atas dapat dipandang sebagai langkah yang sangat spektakuler dan revolusioner. Ia tidak saja mengubah tatanan masyarakat Arab pada waktu itu, tetapi juga mendekonstruksi pilar-pilar peradaban, kebudayaan, dan tradisi yang diskriminatif dan yang misoginis, yang telah sekian lama dipraktekkan masyarakat sebelumnya. Pada masa pra-Islam, harga perempuan sangat rendah. Mereka dianggap barang atau benda yang dapat diperlakukan apa saja, bahkan sering kali orang menganggap melahirkan perempuan sebagai sesuatu yang memalukan dan ditolerir jika anak perempuan tersebut dikubur 
hidup-hidup (Muhammad, 2007: 22).

Namun dalam perkembangan situasi sosial yang ada, ditemukan banyak sekali keadaan yang tidak ideal. Keadaan yang terkadang bertolak belakang dengan apa yang dirancang-bangunkan oleh Nabi Muhammad SAW. Salah satunya adalah upaya superioritas laki-laki atas perempuan secara mutlak. Padahal keberadaaan Nabi pada periode awal Islam membawa misi egalitarianisme atau kesetaraan antara lelaki dan perempuan. Tidak untuk mengunggulkan satu jenis kelamin dan menegasikan jenis kelamin lainnya.

Ketimpangan hubungan laki-laki dan perempuan yang berujung pada ketidakadilan terhadap perempuan ini disebabkan antara lain mitosmitos yang disebarluaskan melalui nilai-nilai dan tafsir ajaran agama yang keliru mengenai keunggulan kaum lelaki. Sebaliknya, tentang perempuan adalah mitos-mitos yang melemahkan kaum perempuan. Laki-laki selalu digambarkan sebagai makhluk yang cerdas, kuat, tidak emosional. Sementara

\begin{tabular}{|c|c|c|}
\hline No & Laki-laki (masculine) & Perempuan (feminin) \\
\hline 1. & Sangat agresif & Tidak terlalu agresif \\
\hline 2. & Independent & Tidak terlalu independent \\
\hline 3. & Tidak emosional & Lebih emosional \\
\hline 4. & Dapat menyembunyikan emosi & Sulit menyembunyikan emosi \\
\hline 5. & Lebih objektif & Lebih subjektif \\
\hline 6. & Tidak mudah terpengaruh & Mudah terpengaruh \\
\hline 7. & Tidak submisif & Lebih submisif \\
\hline 8. & $\begin{array}{l}\text { Sangat menyukai pengetahuan } \\
\text { eksakta }\end{array}$ & Kurang menyukai eksakta \\
\hline 9. & Tidak mudah goyah terhadap krisis & Mudah goyah menghadapi krisis \\
\hline 10. & Lebih aktif & Lebih pasif \\
\hline 11. & Lebih kompetitif & Kurang kompetitif \\
\hline 12. & Lebih logis & Kurang logis \\
\hline 13. & Lebih mendunia & Berorientasi ke rumah \\
\hline 14. & Lebih terampil berbisnis & Kurang terampil berbisnis \\
\hline 15. & Lebih berterus terang & Kurang berterus terang \\
\hline 16. & $\begin{array}{l}\text { Memahami seluk beluk perkem- } \\
\text { bangan dunia }\end{array}$ & $\begin{array}{l}\text { Kurang memahami seluk beluk } \\
\text { perkembangan dunia }\end{array}$ \\
\hline 17. & $\begin{array}{l}\text { Berperasaan tidak mudah tersing- } \\
\text { gung }\end{array}$ & Berperasaan mudah tersinggung \\
\hline 18. & Lebih suka berpetualang & Tidak suka berpetualang \\
\hline 19. & Mudah mengatasi persoalan & Sulit mengatasi persoalan \\
\hline
\end{tabular}




\begin{tabular}{lll}
\hline 20. & Jarang menangis & Lebih sering menangis \\
\hline 21. & $\begin{array}{l}\text { Umumnya tampil sebagai pemi- } \\
\text { mpin }\end{array}$ & $\begin{array}{l}\text { Tidak umum tampil sebagai pemi- } \\
\text { mpin }\end{array}$ \\
\hline 22. & Penuh rasa percaya diri & Kurang rasa percaya diri \\
\hline 23. & $\begin{array}{l}\text { Lebih banyak mendukung sikap } \\
\text { agresif }\end{array}$ & $\begin{array}{l}\text { Kurang senang terhadap sikap } \\
\text { agresif }\end{array}$ \\
\hline 24. & Lebih ambisi & Kurang ambisi \\
\hline 25. & Lebih mudah membedakan antara & $\begin{array}{l}\text { Sulit membedakan antara rasa dan } \\
\text { rasio }\end{array}$ \\
\hline rasa dan rasio & Lebih merdeka & Kurang merdeka \\
\hline 27. & Tidak canggung dalam penampilan & Lebih canggung dalam penampilan \\
\hline 28. & Pemikiran lebih unggul & Pemikiran kurang unggul \\
\hline 29. & Lebih bebas berbicara & Kurang bebas berbicara \\
\hline
\end{tabular}

perempuan adalah makhluk yang lemah, bodoh, emosional dan tidak mandiri (Munti, 1999:38-39). Pandangan berbasis ajaran agama seringkali menempatkan perempuan dalam kerangka tidak lebih hebat dibandingkan perempuan (Umar, 2001: 43) sebagaimana berikut"

Tabel 1. Perbandingan Sifat Laki-Laki dan Perempuan

Pandangan keagamaan yang muncul dalam literatur tafsir klasik terhadap ayat-ayat gender selama ini bersifat bias keberpihakan kepada laki-laki, di mana laki-laki diberikan peran dominan dalam dunia publik, sedangkan perempuan diberikan peran di wilayah privat. Meskipun pemikiran demikian sangat tepat untuk konteks sosial saat itu, pembagian peran berdasarkan jenis kelamin jelas merugikan perempuan dan menguntungkan laki-laki. Pembagian seperti tidak sejalan dengan semangat yang ingin ditumbuhkan oleh al-Qur'an. (Umar dan Lubis, 2004:136)

Dengan pola seperti ini, menjadi wajar jika aspek kultural—yang menjadi komponen kompromi dengan fiqih—-telah melahirkan fiqih yang sangat tidak adil gender. Perempuan dinilai separoh dari laki-laki dalam persoalan aqiqah, kesaksian, waris), mendapatkan label negatif saat haid, dibatasi dan diproteksi (mahram), didiskriminasi (dilarang jadi imam shalat, pemimpin negara, hakim, saksi [hak Allah]) dan lain-lain. Kesemuanya tidak relevan dengan perkembangan realitas sosial budaya yang semakin egaliter (Najib: i).

Masyarakat Desa Grobog Wetan dalam pelaksanaan ajaran agama dapat dikatakan sebagai masyarakat religius. Materi pengajian banyak berhubungan 
dengan tema-tema fikih. Dalam seminggu, pengajian terus dilakukan tiap hari di berbagai blok (komplek/pedukuhan). Intensifikasi yang kemudian memunculkan istilah Senenan, Selasanan, Reboan, Kemisan, Jumatan, Saptunan dan Mingguan. Istilah ini untuk mengidentifikasi pengajian yang dilakukan pada hari-hari tersebut. Pada hari yang sama pula, kegiatan pengajian Senenan misalnya, tidak hanya ada satu pengajian yang digelar. Di pedukuhan Jati misalnya, ada pengajian Senenan ibu-ibu yang dilaksanakan oleh Jamiyyah AlMunawaroh sementara di hari yang sama ada kelompok pengajian Ibu-Ibu yang dilaksanakan di Pondok Pesantren Nurul Huda. Pelaksanaan pengajian dapat dilaksanakan baik pada siang harinya saja maupun malam harinya. Kesemuanya Senin juga ada pengajian yang tetap merujuk kepada nomenklatur senenan. Bedanya jika malam senin dilaksanakan oleh bapak-bapak. Pola seperti ini juga jamak terjadi di pengajian pada hari-hari lain. Dengan demikian dalam satu minggu baik siang maupun malam, Desa Grobog Wetan penuh dengan pengajian yang dalam materi ceramah agamanya lebih banyak berorientasi fikih.

Arus utama masyarakat menjadikan produk fikih yang disampaikan penceramah sebagai rujukan dalam menjalani kehidupan sehari-hari dan kebenaran yang harus dipatuhi. Termasuk dalam kaitannya relasi lelakiperempuan. Seorang perempuan, baik sebagai istri, anak perempuan, adik perempuan atau kakak perempuan harus patuh pada suami, adik laki-laki atau kakak laki-laki dalam berbagai dinamika kehidupannya. Termasuk dalam hal politik desa atau pemilihan kepala desa. Perempuan harus patuh pada laki-laki dalam menentukan kepada siapa suara diberikan dan kepada siapa perempuan itu melakukan sinoman demi suksesnya calon yang didukung laki-laki. Mendukung pilihan politik suami dan sinoman politik sama dengan menjaga harga diri suami. Kemenangan pilihan politik suami adalah kemenangan politik istri atau saudara perempuan lainnya. Dalam keadaan ini, tidak nampak perlawanan dari perempuan. Semuanya berjalan dengan lancer. Intensifikasi pengajian yang berbasis fikih selama ini telah terbukti. Ada perasaan atau kekhawatiran berdosa jika melawan perintah laki-laki dalam bingkai politik. Peran politik perempuan dalam suksesi pemilihan kepala desa menempatkan perempuan menjadi 'alat' konsolidasi, meramu amunisi politik, pilar utama dalam kampaye dan menjaga konstituen agar tetap solid dalam satu barisan 
pilihan.

\section{Makna Kesetaraan Gender Pada Masyarakat Lokal}

Feminisme adalah sebuah ideologi pembebasan perempuan karena yang melekat dalam semua pendekatannya adalah keyakinan bahwa perempuan mengalami ketidakadilan karena jenis kelaminnya hanya karena ia adalah perempuan. Sebagai sebuah ideologi, feminisme digambarkan dengan mata, hati, dan tindakan, yaitu bahwa dia menyadari, melihat, mengalami, adanya penindasan hegemoni, diskriminasi dan penindasan yang terjadi pada perempuan, mempertanyakannya, menggugat, dan mengambil aksi untuk merubahnya (Aziz, 2007:63).

Konsep Feminisme yang lahir di Barat, berkembang sebagai isu global yang melintas ruang-ruang sosial-politik negara-negara yang ada. Dalam kondisi ini, perlu mengintegrasikan pengalaman kaum miskin atau perempuan dari berbagai budaya (Connolly, 2002: 99-100), termasuk di Indonesia.

Dalam babakan sejarah keraton Jawa pula muncul sebuah konsepsi tentang relasi lelaki-perempuan yang terangkum dalam apa yang disebut sebagai Katuranggan. Dalam ekspresibudaya katuranggan dengan data-datanya yang empirik, sebenarnya orang Jawa tetap memandang masalah seksual tetap bersifat esensialis, yakni seks sebagai wahana prokreasi. Dalam pandangan ini orang Jawa tetap mempertahankan pandangannya yang esensialis tentang seks, tetapi ia juga menjadikan seks sebagai wahana pemuasan nafsu-nafsu penikmatan terhadap hidup atau watak hedonistik (Sukatno, 2002: 116-117). Peter F. Drucker, sebagaimana dikutip Otto, dalam hal ini juga mengatakan hal yang sama, bahwa strukturalisme memandang manusia lebih diciptakan untuk keperluan suatu sistem atau struktur. Perempuan dikonstruksi sebagai alat politik tanpa memperhatikan pembagian kekuasaan atas dasar pekerjaan politik yang dilakukan perempuan.

Dalam pandangan feminisme, perempuan berhak melakukan identifikasi diri, yaitu keyakinan perempuan terhadap individualitas dan potensi, serta persepsi mengenai dirinya sebagai anggota komunitas perempuan.Dalam masyarakat patriarki, perempuan diidentifikasi secara keliru karena mereka diasingkan dari pengalaman otentik. Identifikasi keliru 
ini dengan demikian harus dihancurkan, karena dengan demikian barulah akan lahir identifikasi diri yang ditentukan oleh perempuan sendiri (Sagala dan Rozana, 2007:43-47)

Feminismetidakmembenarkan adanya absolutisasipemikiranfeminisme. Feminisme tidak dapat menjadikan model perempuan Barat atau perempuan Asia sebagai contoh feminisme yang paling benar. Jika ini terjadi maka akan terjadi imperialisasi budaya juga diperankan oleh feminisme. Dengan demikian feminisme meneropong permasalahan dalam kapasitas masing-masing konteks yang ada dengan tetap bersandar pada situasi sosial yang ada.

Bahwa perbedaan yang kodrati adalah permanen dan perbedaan perilaku adalah hasil rekayasa sosial merupakan kata kunci dalam memahami gender dan kontekstualisasinya. Hal ini penting agar tidak terjadi kesalahpahaman bahwa diskursus gender adalah sesat atau melawan keputusan Tuhan dalam perbedaan laki-laki dan perempuan. Seperti yang terjadi di Desa Grobog Wetan tentang tradisi sinoman yang dominan dengan peran perempuan.Hal ini merupakan rekayasa sosial yang di dalamnya keterlibatan kepentingankepentingan manusia yang bersifat duniawi atau profan berlangsung dari masa ke masa.

Tradisi sinoman yang sudah melekat pada masyarakat Jawa, terutama setiap aktivitas dan kegiatan yang membutuhkan banyak orang memiliki makna sosial, politik dan agama. Ketiganya dalam konteks tertentu tidak dapat dipisahkan. Ditinjau dari maknanya, masyarakat Desa Grobog Wetan meyakini bahwa sinoman menjadi perekat sosial agama dan politik sekaligus. Sinoman dapat mempertemukan masyarakat tanpa melihat status sosial dan mempertemukan mereka dalam satu kepentingan dengan dilandasi semangat ibadah demi tercapainya kepentingan politik bersama.

Sidar, istri salah seorang RT lain misalnya, membantu tugas suaminya adalah ibadah. Memberikan secara cuma-cuma, menyediakan makanan dan minuman di rumah calon kepala desa atas perintah suami juga dimaknai sebagai ibadah. Patuh kepada perintah suami adalah ibadah. Para perempuan memaknai sinoman sebagai bentuk partnership dengan lelaki dalam konteks kekeluargaan, transformasi sosial, politik dan ekonom.Perempuan dengan berbagai latar belakang pertimbangannya memaknai sinoman sebagai media 
untuk menjaga keseimbangan politik desa.

Pada ranah politik pemilihan kepala desa misalnya, seorang istri melakukan sinoman sebagai media diplomasi yang mewakili keluarganya dalam membangun jaringan politik dalam konteks yang lebih luas.Ini akan semakin menguat ketika dari keluarganya menghendaki jabatan politik bagi adik atau saudara lainnya. Seorang istri seperti menjadi wakil suami dalam negoisasi, kampanye atau meyakinkan warga untuk memilih calon kepala desa sebagaimana dikehendaki keluarga istri. Kelak saat calonnya terpilih, sinoman ini akan menjadi pertimbangan kultural sekaligus politik seorang kepala desa untuk mengangkat saudara atau adik/adik ipar istri dalam jabataan politik di desa, baik RT, RW. Dikatakan kultural karena mekanismenya tidak tercatat dan terstruktur dalam peraturan tapi mengikat secara 'perasaan' namun berdimensi politis.

Seorang istri bawahan kepala desa juga merupakan perwujudan atau manifestasi politis bagi suaminya. Seorang istri, menjadi simbol yang "menjelaskan" penghormatan suami terhadap atasannya.Ketika atasannya sedang melaksanakan hajatan, maka seorang istri bawahan menjadi "utusan" suaminya untuk melaksanakan sinoman di rumah atasannya. Biasanya, "utusan" tersebut akan berkonsorsium dengan "utusan" lainnya di bawah komando sang istri atasan. Peran ini menjadi penting bagi kedudukan suami bawahan, setidaknya dalam menjaga ritme pekerjaan di kantor sehariseharinya. Seorang istri dalam hal ini menjadi diplomat lokal atau katalisator bagi kedudukan suaminya.Di sinilah nampak power istri atau perempuan sebagai aktor politik yang halus dalam kerangka sinoman.Perempuan, meski tidak terstruktur, mampu mempengaruhi dan menjaga dinamika politik desa.

\section{Simpulan}

Peran perempuan dalam sinoman politik di Desa Grobog Wetan terhubung dengan pemahaman agama tentang ketundukan istri atas pilihan suami sebagai imam/pemimpin. Sinoman politik menjembatani kepentingan suami sekaligus memberikan ruang bagi istri dalam berinteraksi sosial dalam hubungan atasan-bawahan, pejabat-warga maupun pembagian kekuasaan. Dengan demikian, partisipasi perempuan di Desa Grobog Weran sangat 
diwarnai oleh pemahaman fikih. Kepatuhan atas keputusan-keputusan strategis suami sebagai imam diikuti oleh perempuan. Formula konsolidasi politik dengan sinoman yang nampaknya tidak bersifat transaksional namun pada kenyataannya memberi nilai tawar yang tinggi bagi kepentingan politik imamnya atau masyarakat pada umumnya. Dalam hal ini perempuan dapatlah disebut setara dengan laki-laki karena memainkan peran penting dalam menjembatani, mengkonsolidir kepentingan bersama dalam ranah politik melalui sinoman.

\section{DAFTAR PUSTAKA}

Aziz, Asmaeny, 2007, Feminisme Profetik, Yogyakarta: Kreasi Wacana.

Connolly, Peter, 2002, Aneka Pendekatan Study Agama, Jogjakarta: LKiS,.

Sagala, R. Valentine dan Ellin Rozana, 2007, Pergulatan Feminisme dan HAM, Bandung: Institut Perempuan.

Fakih, Mansour, 2001, Analisis Gender dan Tranformasi Sosial, Jogjakarta: Pustaka Pelajar

Waters, Malcolm , 1994, Modern Sociological Theory, London: Sage Publication

Muhammad, Husein. 2007, Fiqih Perempuan: Refleksi Kiai atas Wacana Agama dan Gender, Jogjakarta: LKiS

Munti, Ratna Batara. 1999, Perempuan sebagai Kepala Rumah Tangga, Jakarta: Lembaga Kajian Agama dan Gender, Perserikatan Solidaritas Perempuan dan The Asia Fondation

Najib, Mohammad, 2001. "Pengantar Penerbit" dalam K.M Iksanudin et.all (ed), Panduan Pengajaran Fiqih Perempuan di Pesantren, Jogkarta: YKF dan Ford Foundation 
Sukatno, Otto, 2002, Seks Para Pangeran: Tradisi dan Ritualisasi Hedonisme Jawa, Jogjakarta: Bentang Budaya.

Umar, Nasarudin dan Amany Lubis. 2004, "Hawa Sebagai Simbol Ketergantungan: Perempuan Dalam Kitab Tafsir” dalam Tentang Perempuan Islam: Wacana dan Gerakan,Jajat Burhanuddin dan Oman Fathurrahman (ed), Jakarta: Gramedia Pustaka Utama

Tim Kantor Menteri Negara Urusan Peranan Wanita, Buku III: Pengantar Teknik Analisa Jender, 1992 